Article

\title{
Novel S. pennellii $\times$ S. lycopersicum Hybrid Rootstocks for Tomato Production with Reduced Water and Nutrient Supply
}

\author{
Jan Ellenberger ${ }^{1}{ }^{\mathbb{D}}$, Aylin Bulut ${ }^{1}$, Philip Blömeke ${ }^{1}$ and Simone Röhlen-Schmittgen ${ }^{1,2, *}$ \\ 1 Department of Horticultural Sciences, Institute of Crop Science and Resource Conservation (INRES), \\ University of Bonn, 53119 Bonn, Germany; ellenberger@uni-bonn.de (J.E.); s7aybulu@uni-bonn.de (A.B.); \\ philip.bloemeke@uni-bonn.de (P.B.) \\ 2 Department of Vegetable Crops, Hochschule Geisenheim University, 65366 Geisenheim, Germany \\ * Correspondence: Simone.RoehlenSchmittgen@hs-gm.de
}

Citation: Ellenberger, J.; Bulut, A.; Blömeke, P.; Röhlen-Schmittgen, S. Novel S. pennellii $\times$ S. lycopersicum Hybrid Rootstocks for Tomato Production with Reduced Water and Nutrient Supply. Horticulturae 2021, 7, 355. https://doi.org/10.3390/

horticulturae7100355

Academic Editor: Antonio Ferrante

Received: 27 August 2021

Accepted: 17 September 2021

Published: 2 October 2021

Publisher's Note: MDPI stays neutral with regard to jurisdictional claims in published maps and institutional affiliations.

Copyright: (c) 2021 by the authors. Licensee MDPI, Basel, Switzerland. This article is an open access article distributed under the terms and conditions of the Creative Commons Attribution (CC BY) license (https:// creativecommons.org/licenses/by/ $4.0 /)$.

\begin{abstract}
Drought stress and nutrient deficiency are limiting factors in vegetable production that will have a decisive role due to the challenges of climate change in the future. The negative effects of these stressors on yield can be mitigated by crop grafting. The increasing demands for resource-use efficiency in crop production, therefore, require the development and phenotyping of more resilient rootstocks, and the selection of appropriate scions. We tested the effect of combined drought stress and nutrient deficiency on yield and fruit quality of the two tomato cultivars 'Lyterno' and 'Tastery' in the greenhouse, grafted onto different rootstock genotypes. The use of four different rootstocks, including two novel S. pennellii $\times$ S. lycopersicum hybrids and the proven-effective use of 'Beaufort', as well as self-grafted plants, allowed conclusions to be drawn about the differential stress mitigation of the rootstocks used. The stress-induced yield reduction of the scion 'Lyterno' can be mitigated more significantly by the novel hybrid rootstocks than by the commercial rootstock 'Beaufort'. At the same time, however, the individual fruit weight and the lycopene content of the fruits were significantly reduced when grafted onto the hybrid rootstocks. In contrast, the cultivar 'Tastery' showed a weak stress response, so that a generally positive influence of the rootstocks independently of the scions could not be demonstrated. We conclude that, particularly for more sensitive cultivars, the selection of more resilient rootstocks offers the potential for sustainable and resource-efficient production not competing with the overall quality of tomatoes.
\end{abstract}

Keywords: grafting; water-use efficiency; nutrient use efficiency; vegetable production

\section{Introduction}

Among abiotic stresses, drought is the most critical threat to agricultural production. It is one of the most common limiting factors influencing plant growth and development [1]. Agronomists are already using a range of management tools to cope with dry conditions in order to harvest sufficient yields at reasonable water and nutrient input [2]. At the same time, both commercial and public organizations across the world continue to develop new crop varieties to cope with the changing environment. Now, as climate change continues, both the physical environment in which agriculture is practiced and the market environment, as well as consumer demands are changing. Customers in parts of Europe are increasingly demanding not only regional products, but also those with a low energy and resource footprint [3]. Modern crop breeding has to keep up with these changing demands. As a result, breeding techniques for resilience and resource-use efficiency are investigated [4]. Different wild crops were included to stabilize yield. Nowadays many tomatoes carry the genetic information of related wild plants [5]. There are many positive known aspects from wild plants to be used. S. pennellii, as a tomato plant example, consists of genes of arid-adapted plant species from South America. S. pennellii can be crossed with tomato [6], but as its fruits are not edible, using S. pennellii-based accessions as a stress-tolerant rootstock seems to be more promising. Although it is possible to use gene 
editing to create de novo plants with beneficial root systems and edible fruits at the same time [7], the lack of public acceptance will likely prevent the commercial use of such plants in Europe in the coming years and perhaps decades [8,9]. Nevertheless, the grafting of horticultural crops remains a method to improve plant growth and yield production [10,11]. Indeed, grafting can be helpful in combining two advantageous characteristics (rootstock and scion) in a single plant. For example, the grafting method is used and researched in vegetable crops to increase yield, fruit quality, and nutrient uptake [12], and also to counteract pathogens and plant diseases $[13,14]$.

For the tomato (Solanum lycopersicum), grafting is also seen as a promising technique to reduce water requirement [15]. The root system of grafted plants is reported to be stronger and more efficient in absorbing water and nutrients [16], which may indirectly improve yield and fruit quality [17]. As tomato production in Germany alone reached 108,000 tons in 2019 and tends to increase worldwide [18], the water and nutrient supply must be optimized and become more sustainable. In this regard, it is useful to resort to certain rootstock cultivars that are more stress-tolerant and to improve fruit quality. Grafting was shown to increase drought-stress tolerance in tomatoes, and drought-stress tolerance varies with the rootstock used [19]. The rootstock cultivar 'Beaufort' was proven to mitigate salt stress to some extent [20], and the water- and nitrogen-use efficiency of fieldgrown tomato 'Florida 47' was increased when grafted onto the rootstock 'Beaufort' [21]. Moreover, the uptake of macronutrients such as nitrogen, phosphorus, and calcium was significantly improved by grafting on 'Beaufort' [22-24]. Although 'Beaufort' is proving to be an efficient rootstock, newly developed cultivars are being hybridized as rootstock that may eventually exceed this performance. For example, novel rootstock cultivars have been obtained by crossing with the wild tomato species Solanum pennellii accession LA716, which is considered to be more tolerant in stress conditions than related tomato species S. lycopersicum [25].

In this study, we compare the yield and water- and nutrient-use efficiency of two commercial tomato lines grafted onto two novel interspecific hybrid rootstocks and the commercial rootstock 'Beaufort' in two fertigation regimes. Given the drought tolerance of $S$. pennellii described in the literature, we hypothesize that $S$. pennellii $\times S$. lycopersicum hybrid rootstocks can limit the yield losses of commercial tomatoes under drought to a minimum. In order to check possible influences on fruit quality, the sugar content of the fruit ( ${ }^{\circ}$ Brix), as well as flavonol and lycopene contents are also analyzed.

\section{Materials and Methods}

\subsection{Plant Material and Treatment}

The research was conducted in a greenhouse located in Meckenheim, Germany (latitude: $50^{\circ} 37^{\prime} 27.7^{\prime \prime} \mathrm{N}$, longitude: $6^{\circ} 59^{\prime} 20.1^{\prime \prime} \mathrm{E}$ ) in 2020. The two tomato (S. lycopersicum) F1 hybrids 'Lyterno RZ F1' (truss tomato) and the 'Tastery RZ F1' (cherry tomato) were self-grafted and grafted onto rootstock cultivars 'HUJ1', 'HUJ2' and 'Beaufort' (De-Ruiter, Bergshenhoek, NL), respectively. 'HUJ1' and 'HUJ2' are interspecific hybrids of an S. lycopersicum variety and the stress-tolerant wild tomato species $S$. pennellii, accession LA716 (described here [26]). In March 2020, one week prior to the scions, rootstock seeds were sown in rockwool substrate blocks (Grodan B.V.). After three weeks, right before grafting, rootstock seedlings were transferred to new rockwool blocks of size $8 \mathrm{~cm} \times 8 \mathrm{~cm} \times 10 \mathrm{~cm}$. The grafting position was below the cotyledons of the rootstock seedlings and sealed with an appropriate clip.

Directly following this process grafted plants were put in a healing chamber for $72 \mathrm{~h}$ and covered with plastic bags to reduce light intensity and increase humidity to enhance the survival rate and then gradually accustomed to lower humidity levels. Thereafter, on May 10th, two plants of the same rootstock-scion combination each were planted in pots filled with Miscanthus $\times$ giganteus substrate. Twelve plants from each of the eight rootstock-scion combinations were prepared for the control and treated groups, respectively. The pots were placed in the greenhouse with an average temperature of 
$21.3^{\circ} \mathrm{C}\left( \pm 3.9^{\circ} \mathrm{C}\right)$ and relative humidity of $77.9 \%( \pm 16.2 \%)$. Fertigation was automatically supplied via drip irrigation. Until the third week in the greenhouse, the plants received a full supply of water and nutrients based on Groher et al. [27], to ensure the consistent growth of all plants. Subsequently, control plants received about $4 \mathrm{~L}$ of fertigation per day (589 $\mathrm{L}$ in 141 days), keeping the substrate at around $80 \%$ humidity by using a soil moisture sensor (SM150 kit, Delta T Devices Ltd., Cambridge, UK), while the treated group received about $2 \mathrm{~L}$ of fertigation per day ( $282 \mathrm{~L}$ in 141 days) (Figure 1 ). The reduced fertigation dose of technically $47.8 \%$ for treated plants is referred to as ' $50 \%$ reduction' from here on.

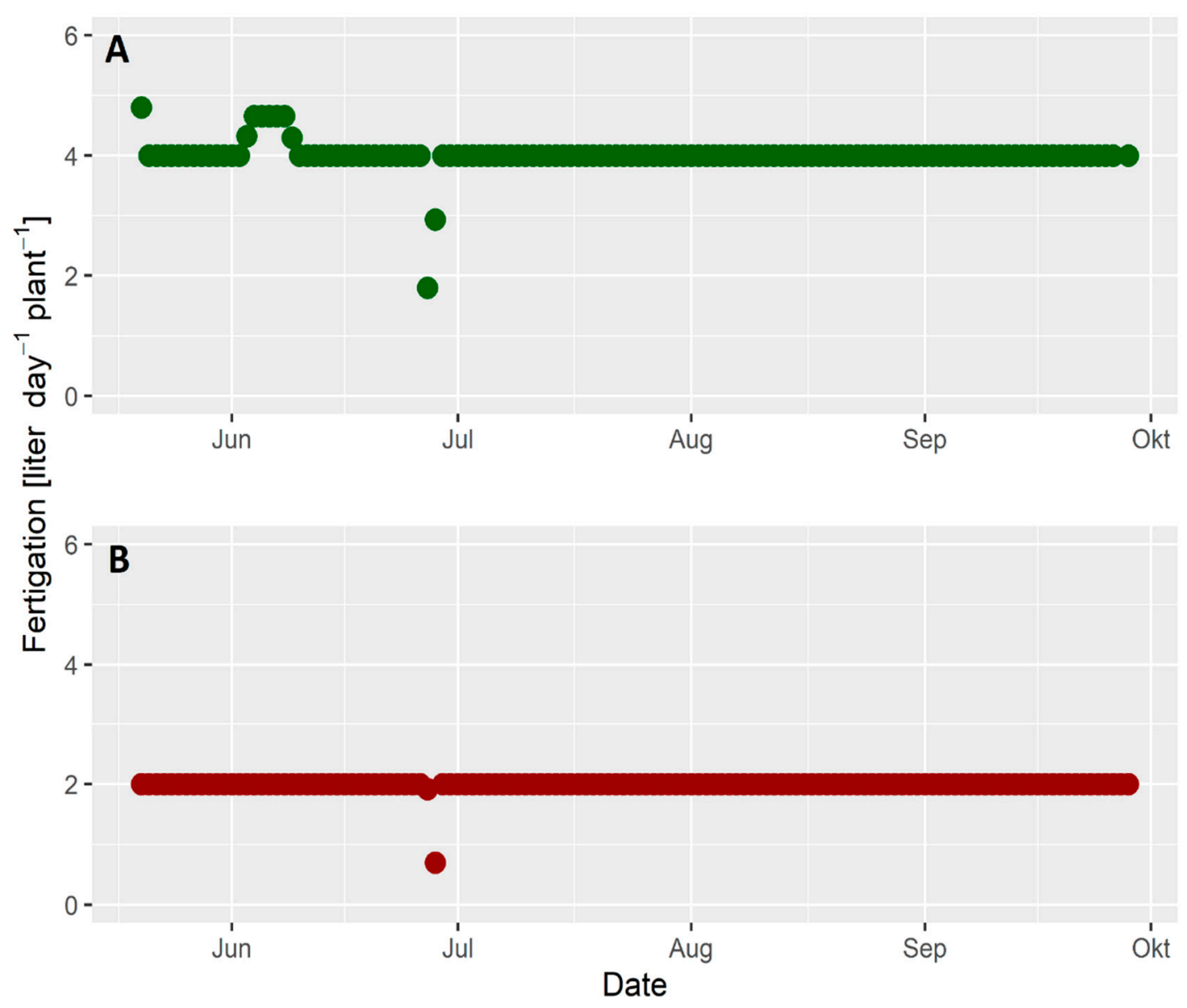

Figure 1. Daily amounts of fertigation for control (A) and drought stress (B). Occasional deviations from the desired $50 \%$ difference in fertigation between treatments occurred due to maintenance work.

\subsection{Determination of Total Yield per Plant, Single Fruit Weight and Water-Use Efficiency}

From the 20th week after sowing, ripe tomatoes were harvested once a week to determine the yield per plant and fruit quality in the greenhouse. Weekly harvesting was carried out until the 27th week. Harvested fruits per plant were categorized as marketable and nonmarketable fruits, based on visual assessment. The fruit number and weight of the harvested fruits of each plant were determined with a technical balance. Water-use efficiency (WUE) was calculated as the quotient of total yield per plant and fertigation per plant throughout greenhouse cultivation.

\subsection{Determination of Total Soluble Solids}

Total soluble solids (TTS) determination was performed on two ripe, marketable 'Lyterno' fruits (truss tomato) and five ripe, marketable 'Tastery' fruits (cocktail tomato), in order to achieve comparable amount of bulk material. Fully ripe fruits were selected from at least two and up to six plants of all rootstock-scion combinations of the control 
and treatment group. A blender was used to mash the tomatoes to a homogeneous mass. The type PAL $^{-1}$ refractometer (ATAGO CO., LTD., Tokyo, Japan) was used to determine the TSS in ${ }^{\circ}$ Brix [\%] of the tomato puree.

\subsection{Determination of Flavonoid and Lycopene Content}

For posterior analysis of lycopene and $\beta$-carotene, we used a protocol that had already been tested before [28]. In short, tomato puree was frozen, freeze-dried and ground for 1 min using a ball mill (MM200, Retsch GmbH, Haan, Germany). Freeze-dried and ground material $(0.1 \mathrm{~g})$ was homogenized and extracted with a $2 \mathrm{~mL}$ acetone-hexane mixture (4:6). The absorbance of the extracts was measured at $453 \mathrm{~nm}, 505 \mathrm{~nm}, 645 \mathrm{~nm}$ and $663 \mathrm{~nm}$ with a UV-visible spectrophotometer (Lambda 35 UV/VIS, spectrophotometer, Perkin Elmer, Waltham, MA, USA). Concentrations of pigments were calculated according to the following equations:

$$
\begin{gathered}
\text { lycopene }[\mathrm{mg} / 100 \mathrm{~mL}]=0.0458_{A 663}+0.204_{A 645}+0.372_{A 505}-0.0806_{A 453} \\
\beta-\text { carotene }[\mathrm{mg} / 100 \mathrm{~mL}]=0.216_{A 663}-0.304_{A 505}+0.452_{A 453}
\end{gathered}
$$

The total flavonoid content was determined according to the slightly modified methodology described by Groher et al. [27]. Briefly, a methanolic extract ( $80 \%$ methanol plus $1.0 \%$ hydrochloric acid) was prepared from $0.05 \mathrm{~g}$ freeze-dried sample material. From an aliquot of the methanolic extract, $1 \mathrm{~mL}$ was mixed with $0.1 \mathrm{~mL}$ of $0.72 \mathrm{~mol} \mathrm{~L}^{-1}$ sodium nitrite solution, $0.1 \mathrm{~mL}$ of $0.75 \mathrm{~mol} \mathrm{~L}^{-1}$ aluminum chloride solution, and $0.1 \mathrm{~mL}$ of $1 \mathrm{~mol} \mathrm{~L}^{-1}$ sodium hydroxide at defined time intervals. After vortexing for $10 \mathrm{~s}, 1.7 \mathrm{~mL}$ water was added to adjust the sample to a final volume of $3.0 \mathrm{~mL}$ After $30 \mathrm{~min}$ of incubation, absorbance was measured at $510 \mathrm{~nm}$ using a UV-visible spectrophotometer (Lambda $35 \mathrm{UV} / \mathrm{VIS}$, spectrophotometer, Perkin Elmer, USA). Quercetin was used as the standard for a linear curve between 0.1 and $1.0 \mathrm{mg} \mathrm{mL}^{-1}$, and the results were expressed as milligrams of quercetin equivalents in dry mass. Analyses were performed in triplicate, and the following equation was used to calculate flavonoid content:

$$
\text { Quercetinequivalents }=4.5709_{A 510}-0.06566
$$

\subsection{Data Analysis}

As a preliminary step, the raw data was aggregated by the single fruit yield and total yield per plant and harvest date. For further analysis, only marketable fruits were taken into account. From those, the single fruit weight and total yield per plant were calculated. Data analysis and visualization was performed in R [29], figures were created using the R-package ggplot2 [30]. Tukey's HSD post hoc tests were used to identify differences in rootstock performance.

\section{Results}

As a result of the differences in fruit shape, Lyterno yields are generally higher than Tastery yields. Mean Lyterno yield per plant in optimal conditions in the seven weeks experimental period was $4906 \mathrm{~g}$ ( $\pm 937 \mathrm{~g})$, with no significant influence of the rootstock used (Figure 2A). For Tastery, the mean yield per plant was $2603 \mathrm{~g}( \pm 250 \mathrm{~g})$ (Figure 2C). When fertigation was reduced, Lyterno yields dropped by around $39 \%$ on average to $2961 \mathrm{~g} \mathrm{(} \pm 899 \mathrm{~g}$ ) (Figure 2B), while the mean reduction in Tastery yields (24\%) was a rather moderate $1978 \mathrm{~g} \mathrm{(} \pm 388 \mathrm{~g}$ ) (Figure 2D). WUE is calculated as the quotient of yield per plant and fertigation per plant. The latter was held constant across rootstock-scion combinations within treated and control plants. The generally observed relative increase in WUE of stressed plants was higher in Tastery than in Lyterno (Tastery: 4.42 to $7.01 \mathrm{~g} / \mathrm{L}$; Lyterno: 8.33 to $10.50 \mathrm{~g} / \mathrm{L}$; Figure 2ii). 


\section{(i) $100 \%$ Fertigation}

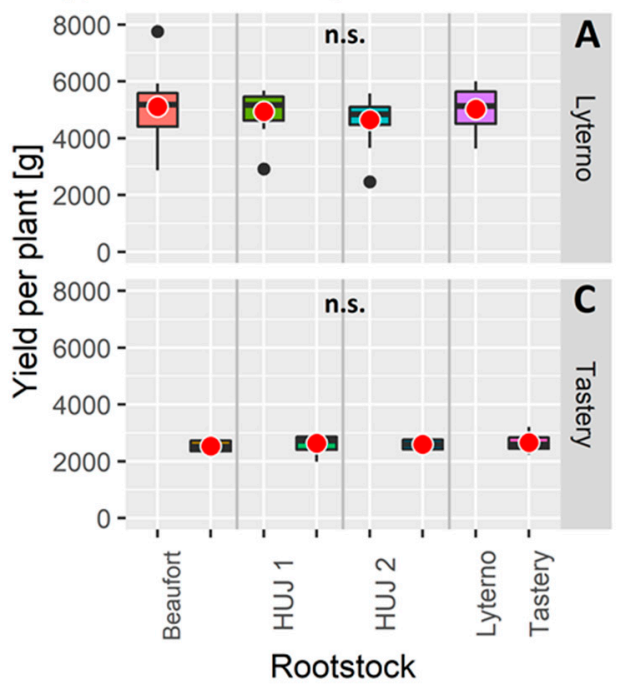

(ii) $100 \%$ Fertigation

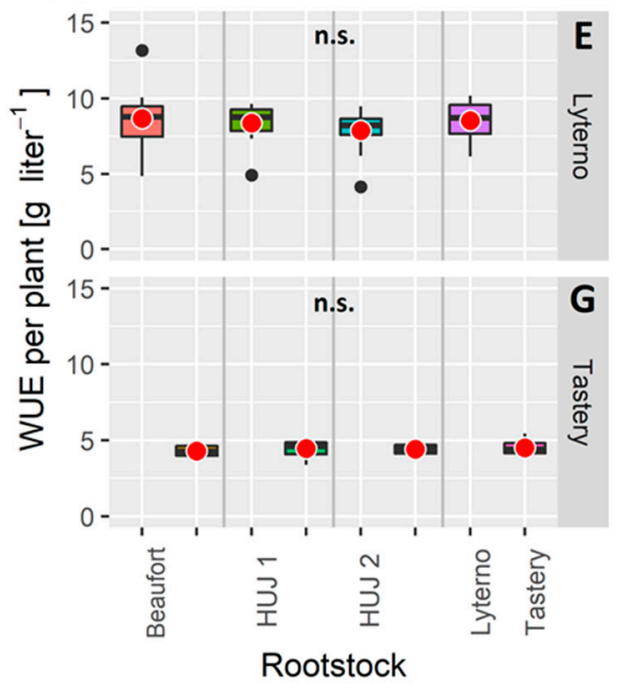

$50 \%$ Fertigation

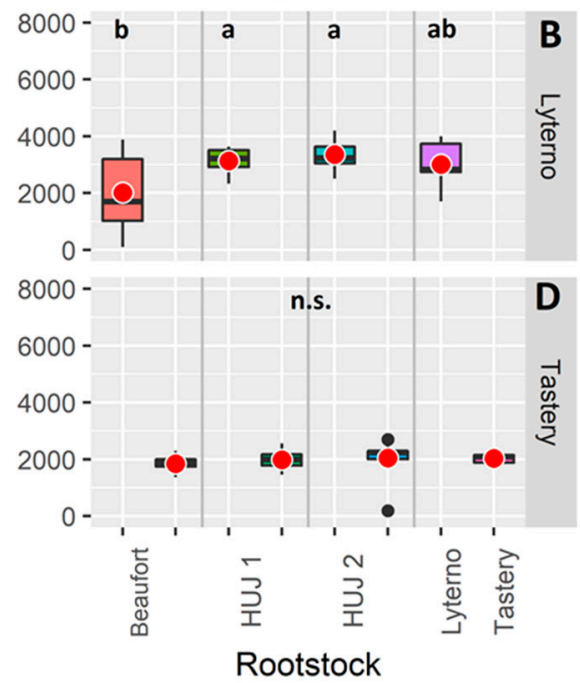

$50 \%$ Fertigation

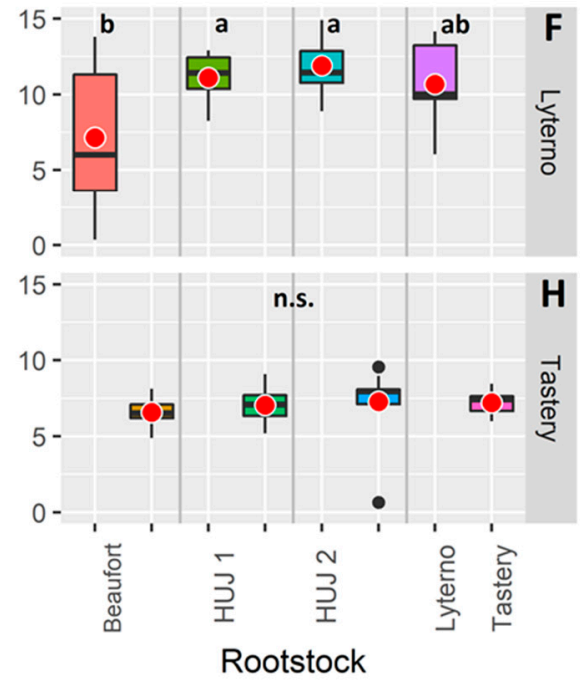

Figure 2. Average yield ((i), top) and water-use efficiency ((ii), bottom) per plant $(\mathrm{n}=12)$ of scions from cultivar 'Lyterno' (A,B,E,F) and 'Tastery' (C,D,G,H) grafted onto different rootstocks and supplied with optimal (A,C,E,G) and reduced (B,D,F,H) fertigation. n.s.: not significant, $p$-value 0.05.

The large standard deviations in the Lyterno yields under reduced fertigation can partly be explained through the rootstock effect: the results of an analysis of variance and subsequent Tukey's HSD tests are presented in Table S1. Plants grafted onto Beaufort yields were significantly lower than those grafted onto HUJ 1 and HUJ 2. Self-grafted controls tended to yield lower than HUJ 1 and HUJ 2, but differences were not significant.

The results of fruit quality analyses of scion 'Lyterno' are presented in Figures 3 and 4. As no change in yield of scion 'Tastery' related to the different rootstock was found (Figure 2C,D), our further analyses focus on Lyterno. Tastery fruit quality parameters are presented in supplementary Figures S1 and S2. 
$100 \%$ Fertigation
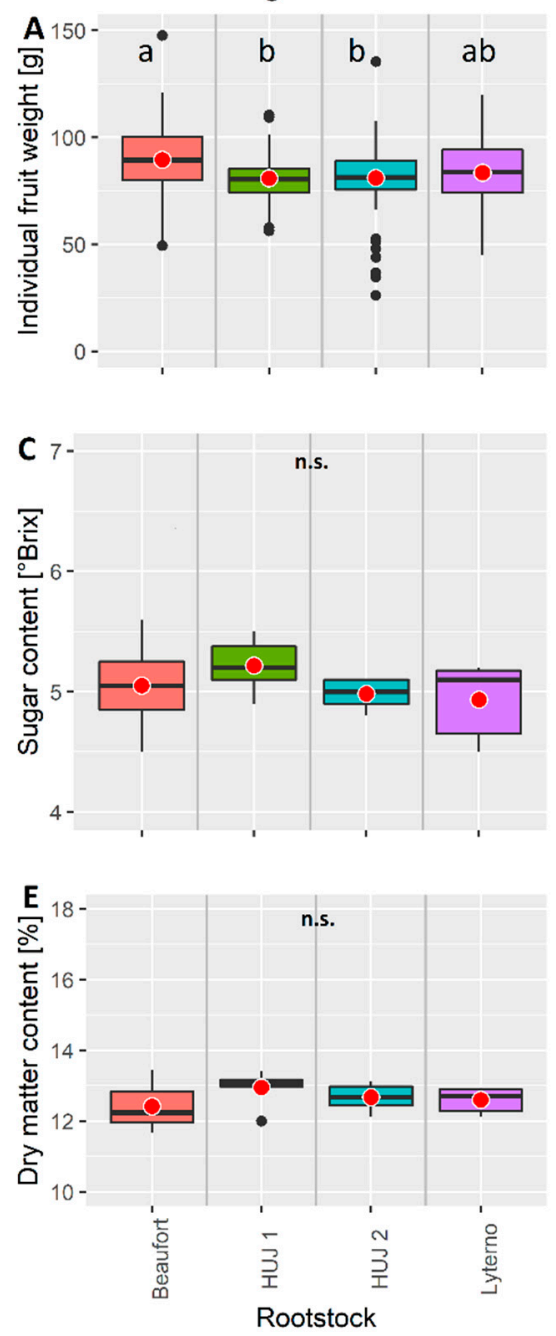

$50 \%$ Fertigation
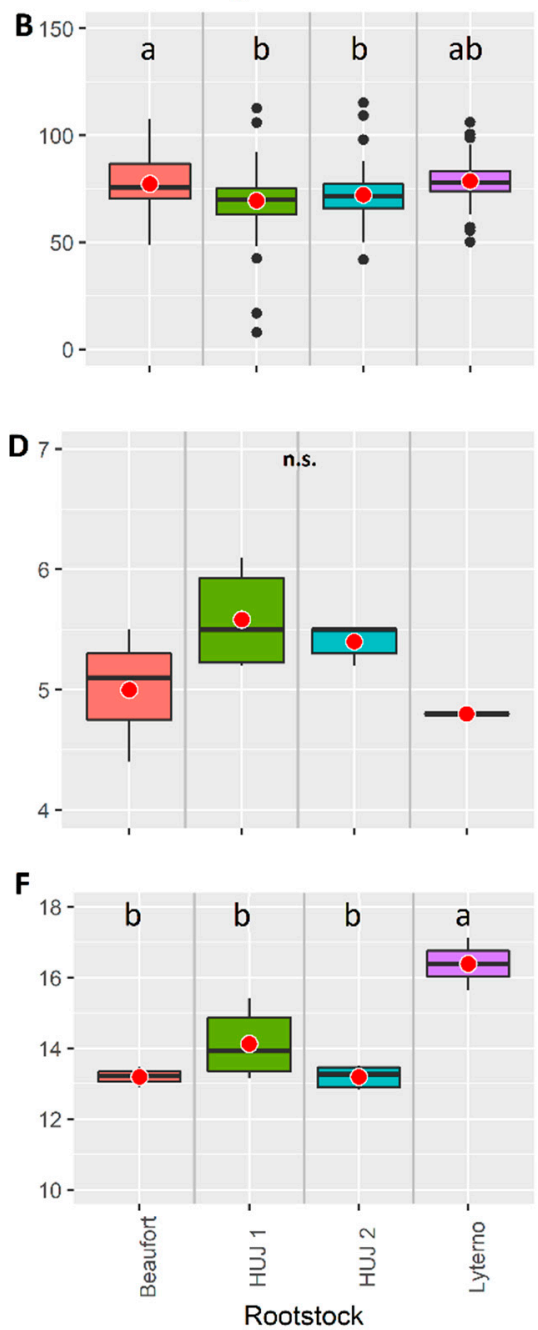

Figure 3. Quality parameters of 'Lyterno' fruits grafted onto four different rootstocks and supplied with optimal (A,C,E) and reduced (B,D,F) fertigation: Individual fruit weight $(\mathrm{g})(\mathrm{n}=49-84)$, $(\mathbf{A}, \mathbf{B})$; total soluble solids ('sugar') content of ripe fruits ( ${ }^{\circ}$ Brix) (fruits of $n=2-6$ plants), (C,D); fruit dry matter content [\%]; $(\mathrm{n}=2-6)(\mathbf{E}, \mathbf{F})$. n.s.: not significant, $p$-value 0.05 .

The individual weight of the Lyterno fruits drops by $11.2 \%$ from $83.1 \mathrm{~g}( \pm 15.0 \mathrm{~g})$ to $73.8 \mathrm{~g}( \pm 13.1 \mathrm{~g})$ when fertigation is reduced. Individual fruit weight of control plants grafted onto Beaufort is significantly higher than grafted onto both HUJ 1 and HUJ 2 $(p<0.01)$ (Figure 3A). In the reduced fertigation regime, self-grafted plants produce on average heavier fruits than scions grafted onto HUJ 1 and HUJ 2 (Figure 3B).

The pattern changes when looking at fruit sugar content. Sugar contents [ $\left.{ }^{\circ} \mathrm{Brix}\right]$ are generally slightly increased when fertigation is reduced: From $5.05^{\circ}$ Brix $\left( \pm 0.29{ }^{\circ}\right.$ Brix $)$ to $5.32{ }^{\circ}$ Brix $\left( \pm 0.43^{\circ}\right.$ Brix $)$. Probably as a result of few marketable fruits from stressed plants grafted onto different rootstocks being available for laboratory analyses $(n=2-6)$, no significant differences in sugar content can be attributed to the different rootstocks. However, a tendency to higher sugar contents in stressed fruits grafted onto HUJ 1 and HUJ 2 is depicted in Figure 3D.

Under the influence of drought stress, the average dry matter content of Lyterno fruits increased from $12.66 \%( \pm 0.51 \%)$ to $13.94 \%( \pm 1.23 \%)$ (Figure $3 \mathrm{E}, \mathrm{F})$. While there were no rootstock dependent differences under optimal fertigation application, the dry matter content of self-grafted plants was higher under reduced fertigation application. 
$100 \%$ Fertigation
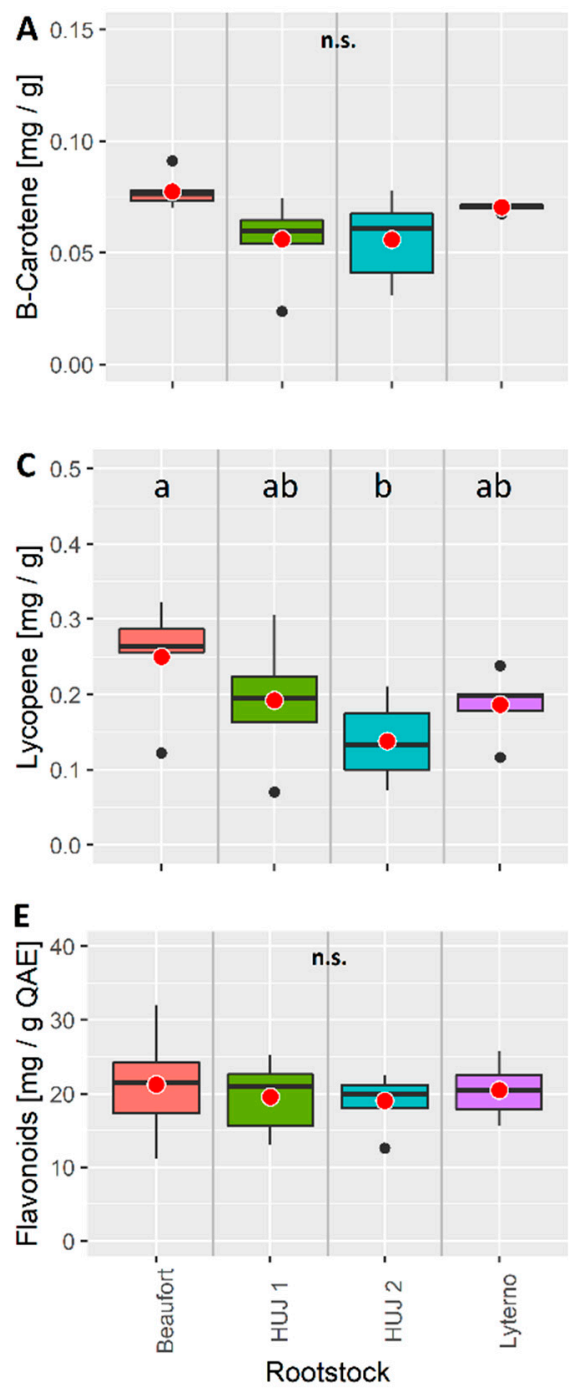

$50 \%$ Fertigation
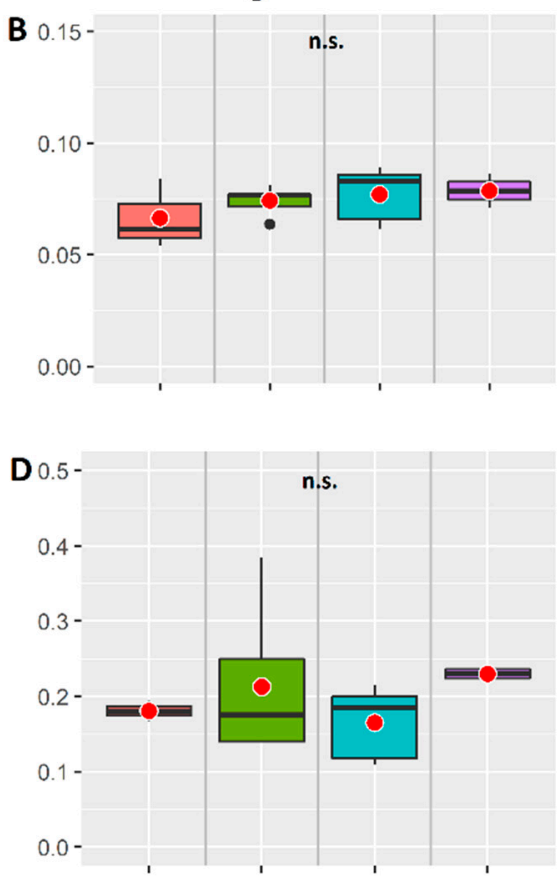

$\mathbf{F}$

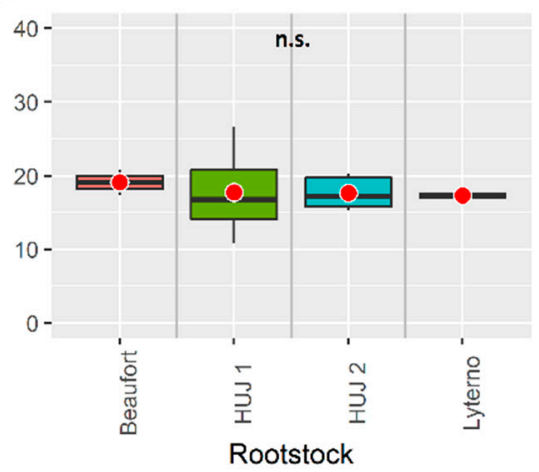

Figure 4. Quality parameters of 'Lyterno' fruits grafted onto four different rootstocks and supplied with optimal (A,C,E) and reduced (B,D,F) fertigation: $\beta$-carotene content (mg/g DM), (A,B); lycopene content (mg/g DM), (C,D); flavonoid content (mg/g DM quercetin equivalents) $(\mathbf{E}, \mathbf{F}) ; \mathrm{n}=(2-6)$. n.s.: not significant, $p$-value 0.05 .

Only minor differences in the $\beta$-carotene, lycopene and flavonoid contents of the 'Lyterno' fruits grafted onto different rootstocks and supplied with optimal or reduced fertigation were detected (Figure 4).

As contents are presented in milligram per gram dry weight (Figure 4), and the dry matter of stressed fruits was on average higher than for control fruits (Figure 3E,F), the contents of $\beta$-carotene, lycopene and flavonoids per fresh matter were higher for stressed than for control fruits (not shown).

A comparison of the lycopene and $\beta$-carotene contents of the fruits indicates a higher responsiveness of $\beta$-carotene than lycopene to the applied changes in fertigation.

\section{Discussion}

A major objective of the present study was to exploit the potential of new genetic material for tomato grafting to target the necessary improvements for horticulture in the scope of climate-related challenges in future. We, therefore, verified to what extent novel hybrid rootstocks (S. pennellii $\times$ S. lycopersicum) could minimize tomato yield loss under limited irrigation conditions, as scarcity of water for irrigation will increase in the 
future [31]. Several studies have shown that remedial action can be provided by combining resilient rootstock and high yielding scions, while the physiological exchange of these plant parts significantly influences overall performance and resilience to environmental stressors. In addition, grafting can improve vegetable quality by enhancing biosynthesis of endogenous phytohormones, and by acquiring and transporting mineral nutrients $[32,33]$. Fruit flavor and nutritional value can be furthermore positively influenced by altered secondary metabolites, and by the concentration of health-promoting compounds, such as lycopene, carotenoids and amino acids [33,34]. Congruently, tomatoes grafted onto efficient rootstocks are also both nutritionally promising and at the same time more tolerant to abiotic and biotic stressors [35], which, besides the sustainable use of resources, in turn offers additional advantages in the case of more frequent and severe incidence of climate-related diseases.

\subsection{Impact of Different Rootstocks on Scion Performance}

Based on plant performance in yield and water-use efficiency, given the data presented (Figure 2i), we can conclude that the two novel rootstocks tested were indeed limiting yield losses of the truss-tomato cultivar Lyterno under drought stress conditions, as compared to the commercial rootstock 'Beaufort'. At the same time, underlining the potential of the new rootstock cultivars in optimal conditions, the yields of scions grafted onto the novel rootstocks were not different from those grafted onto 'Beaufort'.

While for the cocktail tomato Tastery, yields did not change depending on the rootstock used, either in optimal or drought conditions, where 5-10\% losses were recorded.

The identical fertigation for plants with both scions apparently resulted in Lyterno being more stressed than Tastery, as can be seen from the greater yield reduction (Figure 2) and the more pronounced differences in fruit quality (Figure 3) for Lyterno.

This is in line with previous studies showing high-yielding performance under optimal conditions when grafted onto 'Beaufort' being advantageous for several scion cultivars $[23,36]$. Here, 'Beaufort' was ascertained as positive in greater stem height and diameter, as well as epigeous dry biomass [23]. Under stress conditions, for example, saline and drought treatment, 'Beaufort' was shown to be more tolerant than other genotypes, such as 'Body', 'Heman', 'Resistar', 'Spirit', 'Vigomax' and 'Vedi' [20], and 'Maxifort', 'Unifort', 'Vedi', 'Kemerit', 'King' 'Kong', 'Spirit', 'Resistar', '500292' and 'Toro' [19], respectively.

With a similarly promising performance, the novel rootstocks 'HUJ1' and 'HUJ2' that are based on the S. pennellii introgression lines (ILs), are considered to maintain stable growth when exposed to salt stress [25]. When stressed, the ILs performed significantly better at maintaining plant growth than the salt-tolerant wild species, as well as parental line LA716.

Nevertheless, for commercially relevant scions, we focused on two production varieties commonly used in central Europe and North America, namely the cocktail tomato 'Tastery' and the truss-tomato 'Lyterno' [37].

At this stage, it remains an open question whether Tastery is generally less responsive to different rootstocks, or whether the lack of rootstock-related differences is due to the relatively mild stress. The fact that yield and fruit weights were lower overall under drought stress was to be expected and was in line with other studies [38,39]. A surprising result was the consistently good performance of the self-grafted plants in our experiment, contradictory to other studies of different cultivars and scion-rootstock combinations [40,41]. The comparably good performance of our 'Tastery-Tastery' plants might be referred to the internal physiological communication between rootstock and scion, being identical for self-grafted plants. This essentially coordinated exchange of endogenous phytohormones, mineral elements, mRNA, and proteins [42], as well as relevant transporters (either influx or efflux carriers) might affect a smoother long-distance signaling of phytohormones through the plant vascular system [43] of genetically identical plants compared to different scion and rootstock genotypes. 


\subsection{Effects of Rootstocks on Water-Use Efficiency during Cultivation Cycle}

In the scope of future challenges of water shortage, water-use efficiency (WUE) is a relevant option to determine plant performance. Reduced irrigation either by an improved WUE of (grafted) tomato genotypes [44] or by effective irrigation management during fruit developmental stages ensures sufficient yield and fruit quality [38].

However, under artificial conditions, the data on yield and WUE should be viewed with caution. Indeed, in order to assess validated data, the irrigation demands of every single plant would need to be considered. On the other hand, such an approach is not yet feasible for commercial-like conditions. Highly sophisticated greenhouse systems based on artificial intelligence might improve the current situation in the near future [45]. Nevertheless, in our experimental case, water demand and, thus, WUE would need to be explored under two separate irrigation regimes to adapt to the cultivar-specific needs of Tastery and Lyterno and/or rootstocks in more depth.

Furthermore, we focused on a rather short time period of productive cultivation cycles. The overall yield performance (Figure 2i) may therefore be used as an indicator for differences in yield among rootstocks, but the absolute values cannot be compared to commercial yields. While production cycles in commercial cultivation in Central European greenhouses last up to 10 months, our calculation of WUE only includes yields from a seven-week period. Moreover, we only started harvesting once all plants produced stable yields, rather than already picking the first tomatoes in the season. By the same token, WUE data presented in Figure 2ii may be used as an indicator for different WUE among rootstocks, but cannot be compared to WUE in commercial production: On the one hand, yield is not comparable to commercial production for the reasons above and on the other hand, water-use data is also different from commercial production, as, e.g., water consumption during plant germination, between grafting and planting out, and finally the water used to flood the Miscanthus substrate after transplanting to ensure plant stand establishment, are not included in our calculations in Figure 2ii. Since these factors were the same for all our experimental plants and rootstock-scion combinations, they can be neglected, but need to be considered when calculating the overall water use and thus, WUE of genotypes.

\subsection{Rootstock Influence on Fruit Quality Parameters}

Fruit quality, such as its nutritional value, taste and odor, is of great importance for consumers and therefore for producers [46]. Grafting has a significant effect on quality parameters improving health-promoting properties and flavor by the altered composition of secondary metabolites [33,34].

Looking at the characteristics of the fruits of plants grafted onto different rootstocks, some interesting results emerged. The two S. pennellii-based rootstocks seemed to favor the production of smaller fruits. Lyterno fruits from plants on these rootstocks were almost universally significantly lighter than the fruits on Beaufort or self-grafted Lyterno (Figure 3A,B). No significant differences were seen for Tastery, but again there is a slight trend toward smaller fruits on S. pennellii-based rootstocks (Figure S1A,B).

The fact that S. pennellii itself produces very small fruits with a fruit weight $<16 \mathrm{~g}$ [47] could be an indication that this trait has been transferred from the rootstock to the scion.

In contrast, we observed a fruit size-enhancing effect of 'Beaufort', resulting in the comparably high individual fruit weight of Lyterno, as was previously described for this type of vigorous interspecific rootstocks $[10,11,36,48]$. This effect on fruit size is significantly influenced by the grafting combination [41], and needs to be distinguished from yield performance that can also be attributed to an enhanced number of tomato fruits rather than an increased average fruit weight [49].

It is known that rootstock mediation affects fruit quality, due to altered water and nutrient uptake, and changes in the source-sink balance impacting ripening behavior $[10,16]$. Therefore, it can be concluded that some rootstocks favor early fruit set, as well as rapid fruit ripening [50]. In particular, the possible faster fruit ripening could have resulted in the 
lower fruit weight of the Lyterno grafted onto 'HUJ1' and 'HUJ2'. Nevertheless, individual fruit weight was further reduced under $50 \%$ fertigation, implying that drought could also have accelerated tomato ripening [27].

Both overall increased dry matter and sugar content, and reduced fruit weight are a logical result of drought stress: with optimal water availability in the root zone, the high sugar concentration in the fruit ensures that water is transported from the root zone into the fruit by osmotic effects. When there is a lack of water, this 'sucking in' of water is not possible, and there is an increased content of soluble substances with a simultaneously reduced fruit weight [51].

The opposite trends observed in Lyterno for yield and fruit weight of S. pennellii-based rootstocks are noteworthy: total yield was relatively high when these rootstocks were used under drought stress (Figure 2B), but at the same time individual fruit weight was relatively low (Figure 3B and Figure S1). This can be explained by the fact that more but smaller fruits reached maturity [49].

These fruits, then, also tend to be sweeter (Figure 3D), which can be seen as another potential advantage provided by the novel rootstocks. Concerning taste and quality, this might be an approach to target current consumer needs.

Surprisingly, in regard to secondary metabolites in Lyterno fruits (Figure 4), we only found a significantly reduced lycopene content for the rootstock 'HUJ2' under optimal fertigation conditions. Here, 'Beaufort' showed the overall highest contents of $\beta$-carotene, lycopene and flavonoids. This is in contrast to previous findings, where 'Beaufort' resulted in a decrease of lycopene concentration of the scions 'Jeremy' and 'Jack' [52,53]. This might be attributed to the specific interaction of rootstock and scion $[10,11]$. However, under $50 \%$ fertigation, slightly reduced but comparably high metabolite contents were analyzed for Lyterno, when individual fruit weight and yield decreased. This is in agreement with previous field trials, where soluble solids, lycopene, and sugar content were increased in the tomato fruit, while fruit yield decreased between 1.9\%-18.2\% [54]. A similar increase in tomato fruit quality parameters was shown for a pot experiment with a two-thirds yield decrease under irrigation with $0.3 \%$ salt concentration in soil [55]. Based on our experiment, it could be argued that the reduction in fertigation also resulted in a reduced volume of 'Lyterno' tomatoes and thus both sugar content and metabolite contents increased in the fruit.

\subsection{Future Perspective of Renewable Substrate for Hydroponics}

Although there were no distinct patterns in the individual grafting combinations with lower fertigation dosages in our experiment, this project is still a sustainable approach for food production targeting resource-efficient tomato production by adjusting both plant performance (via grafting) and crop management. Eventually, a sustainable and more environmentally friendly substrate of Miscanthus $\times$ giganteus was used. In the study of Kraska et al. [56], it was shown that Miscanthus as shreds, chips and fibers does not differ much in comparison to rockwool as a substrate for the cumulative fruit yield (g/plant), which highlights in our experiment the fact, that the use of Miscanthus $\times$ giganteus should not negatively impact the yield measurement. Moreover, the yields and fruit quality of cucumber and tomatoes grown on Miscanthus as a potential alternative to rockwool as a growing medium for vegetables $[57,58]$ and is overall seen as a promising alternative to rockwool as a growing medium for tomatoes in soilless cultivation [56].

To determine the optimal water and nutrient requirements in grafted 'Lyterno' and 'Tastery' tomato plants, further studies will need to be conducted in order to gain a more detailed insight into the interaction between rootstock and scions, as well as the potential to identify the genotype combinations being more tolerant towards drought stress and nutrient limitations. Ultimately, besides sustainability, it also makes financial sense to graft plants and thereby apply less water or nutrients for the same yield, than not grafting and thereby use up many limited resources, without losing fruit quality. 
Supplementary Materials: The following are available online at https: / www.mdpi.com/article/ 10.3390/horticulturae7100355/s1, Table S1: Tukey comparison of mean differences for plants with the scion Lyterno under stress conditions. Figure S1: Quality parameters of "Tastery" fruits grafted on four different rootstocks and supplied with optimal and reduced fertigation. Figure S2: Quality parameters of "Tastery" fruits grafted on four different rootstocks and supplied with optimal and reduced fertigation. Figure S3: Comparison of lycopene and $\beta$-carotene contents of ripe tomatoes from 8 rootstock * scion - combinations supplied with optimal and reduced fertigation.

Author Contributions: Conceptualization, J.E., S.R.-S.; data analysis, J.E., A.B., P.B.; methodology, J.E.; writing—original draft preparation, J.E., A.B., P.B.; writing—review and editing, J.E., S.R.-S., A.B. and P.B. All authors have read and agreed to the published version of the manuscript.

Funding: J.E. received funding from the European Union's Horizon 2020 research and innovation program under the Grant Agreement No. (727929) (TOMRES).

Institutional Review Board Statement: Not applicable.

Informed Consent Statement: Not applicable.

Data Availability Statement: Raw data is available on request from the corresponding author.

Acknowledgments: The authors thank Dani Zamir, Hebrew University of Jerusalem, for providing S. pennellii $\times$ S. lycopersicum seeds. We also thank the technical staff of the Institute for Crop Science and Resource Conservation of Bonn University for their cooperation.

Conflicts of Interest: The authors declare no conflict of interest.

\section{References}

1. Sánchez-Rodríguez, E.; Leyva, R.; Constán-Aguilar, C.; Romero, L.; Ruiz, J.M. Grafting under Water Stress in Tomato Cherry: Improving the Fruit Yield and Quality. Ann. Appl. Biol. 2012, 161, 302-312. [CrossRef]

2. Ullah, H.; Santiago-Arenas, R.; Ferdous, Z.; Attia, A.; Datta, A. Chapter Two-Improving Water Use Efficiency, Nitrogen Use Efficiency, and Radiation Use Efficiency in Field Crops under Drought Stress: A Review. Adv. Agron. 2019, 156, 109-157. [CrossRef]

3. Cherry, C.; Scott, C.; Barrett, J.; Pidgeon, N. Public Acceptance of Resource-Efficiency Strategies to Mitigate Climate Change. Nat. Clim. Chang. 2018, 8, 1007-1012. [CrossRef]

4. Cuartero, J.; Bolarin, M.C.; Asins, M.J.; Moreno, V. Increasing Salt Tolerance in the Tomato. J. Exp. Bot. 2006, 57, 1045-1058. [CrossRef] [PubMed]

5. Dempewolf, H.; Baute, G.; Anderson, J.; Kilian, B.; Smith, C.; Guarino, L. Past and Future Use of Wild Relatives in Crop Breeding. Crop. Sci. 2017, 57, 1070-1082. [CrossRef]

6. Bolger, A.; Scossa, F.; Bolger, M.E.; Lanz, C.; Maumus, F.; Tohge, T.; Quesneville, H.; Alseekh, S.; Sørensen, I.; Lichtenstein, G.; et al. The Genome of the Stress-Tolerant Wild Tomato Species Solanum Pennellii. Nat. Genet. 2014, 46, 1034-1038. [CrossRef]

7. Zsögön, A.; Čermák, T.; Naves, E.R.; Notini, M.M.; Edel, K.H.; Weinl, S.; Freschi, L.; Voytas, D.F.; Kudla, J.; Peres, L.E.P. De Novo Domestication of Wild Tomato Using Genome Editing. Nat. Biotechnol. 2018, 36, 1211-1216. [CrossRef]

8. Zimny, T.; Sowa, S.; Tyczewska, A.; Twardowski, T. Certain New Plant Breeding Techniques and Their Marketability in the Context of EU GMO Legislation-Recent Developments. New Biotechnol. 2019, 51, 49-56. [CrossRef] [PubMed]

9. Callaway, E. CRISPR Plants Now Subject to Tough GM Laws in European Union. Nature 2018, 560, 16. [CrossRef]

10. Kyriacou, M.C.; Rouphael, Y.; Colla, G.; Zrenner, R.; Schwarz, D. Vegetable Grafting: The Implications of a Growing Agronomic Imperative for Vegetable Fruit Quality and Nutritive Value. Front. Plant Sci. 2017, 8, 741. [CrossRef]

11. Rouphael, Y.; Schwarz, D.; Krumbein, A.; Colla, G. Impact of Grafting on Product Quality of Fruit Vegetables. Sci. Hortic. 2010, 127, 172-179. [CrossRef]

12. Alan, O.; Ozdemir, N.; Gunen, Y. Effect of Grafting on Watermelon Plant Growth, Yield and Quality. J. Agron. 2007, 6, 362-365. [CrossRef]

13. López-Pérez, J.-A.; Le Strange, M.; Kaloshian, I.; Ploeg, A.T. Differential Response of Mi Gene-Resistant Tomato Rootstocks to Root-Knot Nematodes (Meloidogyne Incognita). Crop. Prot. 2006, 25, 382-388. [CrossRef]

14. Rivard, C.L.; O'Connell, S.; Peet, M.M.; Welker, R.M.; Louws, F.J. Grafting Tomato to Manage Bacterial Wilt Caused by Ralstonia Solanacearum in the Southeastern United States. Plant Dis. 2012, 96, 973-978. [CrossRef] [PubMed]

15. Estan, M.T.; Martinez-Rodriguez, M.M.; Perez-Alfocea, F.; Flowers, T.J.; Bolarin, M.C. Grafting Raises the Salt Tolerance of Tomato through Limiting the Transport of Sodium and Chloride to the Shoot. J. Exp. Bot. 2005, 56, 703-712. [CrossRef] [PubMed]

16. Savvas, D.; Colla, G.; Rouphael, Y.; Schwarz, D. Amelioration of Heavy Metal and Nutrient Stress in Fruit Vegetables by Grafting. Sci. Hortic. 2010, 127, 156-161. [CrossRef] 
17. Flores, F.B.; Sanchez-Bel, P.; Estañ, M.T.; Martinez-Rodriguez, M.M.; Moyano, E.; Morales, B.; Campos, J.F.; Garcia-Abellán, J.O.; Egea, M.I.; Fernández-Garcia, N.; et al. The Effectiveness of Grafting to Improve Tomato Fruit Quality. Sci. Hortic. 2010, 125, 211-217. [CrossRef]

18. Statistisches-Bundesamt. Erntemenge von Tomaten in Deutschland in Den. Jahren 2001 Bis 2019 (in 1.000 Tonnen); Statistisches Bundesamt Destatis: Wiesbaden, Germany, 2020.

19. Altunlu, H.; Gul, A. Increasing Drought Tolerance of Tomato Plants by Grafting. Acta Hortic. 2012, 183-190. [CrossRef]

20. Öztekin, G.B.; Tuzel, Y. Salinity Response of Some Tomato Rootstocks at Seedling Stage. Afr. J. Agric. Res. 2011, 6, 4726-4735. [CrossRef]

21. Djidonou, D.; Zhao, X.; Simonne, E.H.; Koch, K.E.; Erickson, J.E. Yield, Water-, and Nitrogen-Use Efficiency in Field-Grown, Grafted Tomatoes. HortScience 2013, 48, 485-492. [CrossRef]

22. Ruiz, J.M.; Romero, L. Nitrogen Efficiency and Metabolism in Grafted Melon Plants. Sci. Hortic. 1999, 81, 113-123. [CrossRef]

23. Leonardi, C.; Giuffrida, F. Variation of Plant Growth and Macronutrient Uptake in Grafted Tomatoes and Eggplants on Three Different Rootstocks. Eur. J. Hortic. Sci. 2006, 71, 97-101.

24. Goto, R.; de Miguel, A.; Marsal, J.I.; Gorbe, E.; Calatayud, A. Effect of Different Rootstocks on Growth, Chlorophyll a Fluorescence and Mineral Composition of Two Grafted Scions of Tomato. J. Plant Nutr. 2013, 36, 825-835. [CrossRef]

25. Frary, A.; Keleş, D.; Pinar, H.; Göl, D.; Doğanlar, S. NaCl Tolerance in Lycopersicon Pennellii Introgression Lines: QTL Related to Physiological Responses. Biol. Plant. 2011, 55, 461-468. [CrossRef]

26. Ofner, I.; Lashbrooke, J.; Pleban, T.; Aharoni, A.; Zamir, D. Solanum Pennellii Backcross Inbred Lines (BILs) Link Small Genomic Bins with Tomato Traits. Plant J. 2016, 87, 151-160. [CrossRef] [PubMed]

27. Groher, T.; Schmittgen, S.; Fiebig, A.; Noga, G.; Hunsche, M. Suitability of Fluorescence Indices for the Estimation of Fruit Maturity Compounds in Tomato Fruits. J. Sci. Food Agric. 2018, 98, 5656-5665. [CrossRef] [PubMed]

28. Nagata, M.; Yamashita, I. Simple Method for Simultaneous Determination of Chlorophyll and Carotenoids in Tomato Fruit. Jpn. Soc. Food Sci. Technol. 1992, 39, 925-928. [CrossRef]

29. R-Core-Team. R: A Language and Environment for Statistical Computing; R Foundation for Statistical Computing: Vienna, Austria, 2020.

30. Wickham, H. ggplot2. In Ggplot2: Elegant Graphics for Data Analysis; Springer: New York, NY, USA, 2009; ISBN 978-0-387-98141-3.

31. Mancosu, N.; Snyder, R.L.; Kyriakakis, G.; Spano, D. Water Scarcity and Future Challenges for Food Production. Water 2015, 7, 975-992. [CrossRef]

32. Wang, Q.; Men, L.; Gao, L.; Tian, Y. Effect of Grafting and Gypsum Application on Cucumber (Cucumis Sativus L.) Growth under Saline Water Irrigation. Agric. Water Manag. 2017, 188, 79-90. [CrossRef]

33. Lee, J.-M.; Kubota, C.; Tsao, S.J.; Bie, Z.; Echevarria, P.H.; Morra, L.; Oda, M. Current Status of Vegetable Grafting: Diffusion, Grafting Techniques, Automation. Sci. Hortic. 2010, 127, 93-105. [CrossRef]

34. Davis, A.R.; Perkins-Veazie, P.; Hassell, R.; Levi, A.; King, S.R.; Zhang, X. Grafting Effects on Vegetable Quality. Am. Soc. Hortic. Sci. 2021, 43, 1670-1672. [CrossRef]

35. Singh, H.; Kumar, P.; Chaudhari, S.; Edelstein, M. Tomato Grafting: A Global Perspective. HortScience 2017, 52, 1328-1336. [CrossRef]

36. Turhan, A.; Ozmen, N.; Serbeci, M.S.; Seniz, V. Effects of Grafting on Different Rootstocks on Tomato Fruit Yield and Quality. Hortic. Sci. 2011, 38, 142-149. [CrossRef]

37. Rijk-Zwaan. Rijk Zwaan North. America I Product Catalogue Fruitcrops; Rijk Zwaan Canada Leamington Demonstration House: Leamington, ON, Canada, 2020.

38. Cui, J.; Shao, G.; Lu, J.; Keabetswe, L.; Hoogenboom, G. Yield, Quality and Drought Sensitivity of Tomato to Water Deficit during Different Growth Stages. Sci. Agric. 2020, 77, 1-9. [CrossRef]

39. Abdulaziz, A.-H.; Abdulrasoul, A.-O.; Thabit, A.; Hesham, A.-R.; Khadejah, A.; Saad, M.; Abdullah, O. Tomato Grafting Impacts on Yield and Fruit Quality under Water Stress Conditions. J. Exp. Biol. Agric. Sci. 2017, 5, 136-147. [CrossRef]

40. Khah, E.M.; Kakava, E.; Mavromatis, A.; Chachalis, D.; Goulas, C. Effect of Grafting on Growth and Yield of Tomato (Lycopersicon Esculentum Mill.) in Greenhouse and Open-Tield. J. Appl. Hortic. 2006, 8, 3-7. [CrossRef]

41. Schwarz, D.; Öztekin, G.B.; Tüzel, Y.; Brückner, B.; Krumbein, A. Rootstocks Can Enhance Tomato Growth and Quality Characteristics at Low Potassium Supply. Sci. Hortic. 2013, 149, 70-79. [CrossRef]

42. Lu, X.; Liu, W.; Wang, T.; Zhang, J.; Li, X.; Zhang, W. Systemic Long-Distance Signaling and Communication between Rootstock and Scion in Grafted Vegetables. Front. Plant Sci. 2020, 11, 460. [CrossRef]

43. Lacombe, B.; Achard, P. Long-Distance Transport of Phytohormones through the Plant Vascular System. Curr. Opin. Plant Biol. 2016, 34, 1-8. [CrossRef]

44. Kumar, P.; Rouphael, Y.; Cardarelli, M.; Colla, G. Vegetable Grafting as a Tool to Improve Drought Resistance and Water Use Efficiency. Front. Plant Sci. 2017, 8, 1130. [CrossRef]

45. Hemming, S.; de Zwart, F.; Elings, A.; Petropoulou, A.; Righini, I. Cherry Tomato Production in Intelligent Greenhouses-Sensors and AI for Control of Climate, Irrigation, Crop Yield, and Quality. Sensors 2020, 20, 6430. [CrossRef] [PubMed]

46. Liu, Z.; Alseekh, S.; Brotman, Y.; Zheng, Y.; Fei, Z.; Tieman, D.M.; Giovannoni, J.J.; Fernie, A.R.; Klee, H.J. Identification of a Solanum Pennellii Chromosome 4 Fruit Flavor and Nutritional Quality-Associated Metabolite QTL. Front. Plant Sci. 2016, 7. [CrossRef] [PubMed] 
47. Talekar, N.S.; Opeña, R.T.; Hanson, P. Helicoverpa Armigera Management: A Review of AVRDC's Research on Host Plant Resistance in Tomato. Crop. Prot. 2006, 25, 461-467. [CrossRef]

48. Pogonyi, Á.; Pék, Z.; Helyes, L.; Lugasi, A. Effect of Grafting on the Tomato's Yield, Quality and Main Fruit Components in Spring Forcing. Acta Aliment. 2005, 34, 453-462. [CrossRef]

49. Savvas, D.; Savva, A.; Ntatsi, G.; Ropokis, A.; Karapanos, I.; Krumbein, A.; Olympios, C. Effects of Three Commercial Rootstocks on Mineral Nutrition, Fruit Yield, and Quality of Salinized Tomato. J. Plant Nutr. Soil Sci. 2011, 174, 154-162. [CrossRef]

50. Fallik, E.; Ilic, Z. Grafted Vegetables-The Influence of Rootstock and Scion on Postharvest Quality. Folia Hortic. 2014, 26, 79-90. [CrossRef]

51. Prudent, M.; Causse, M.; Génard, M.; Tripodi, P.; Grandillo, S.; Bertin, N. Genetic and Physiological Analysis of Tomato Fruit Weight and Composition: Influence of Carbon Availability on QTL Detection. J. Exp. Bot. 2009, 60, 923-937. [CrossRef]

52. Misković, A.; Ilin, Z.; Marković, V. Effect of Different Rootstock Type on Quality and Yield of Tomato Fruits. Acta Hortic. 2009, 807, 619-624. [CrossRef]

53. Riga, P.; Benedicto, L.; García-Flores, L.; Villaño, D.; Medina, S.; Gil-Izquierdo, Á. Rootstock Effect on Serotonin and Nutritional Quality of Tomatoes Produced under Low Temperature and Light Conditions. J. Food Compos. Anal. 2016, 46, 50-59. [CrossRef]

54. Li, J.; Chen, J.; Qu, Z.; Wang, S.; He, P.; Zhang, N. Effects of Alternating Irrigation with Fresh and Saline Water on the Soil Salt, Soil Nutrients, and Yield of Tomatoes. Water 2019, 11, 1693. [CrossRef]

55. Yang, H.; Du, T.; Mao, X.; Ding, R.; Shukla, M.K. A Comprehensive Method of Evaluating the Impact of Drought and Salt Stress on Tomato Growth and Fruit Quality Based on EPIC Growth Model. Agric. Water Manag. 2019, 213, 116-127. [CrossRef]

56. Kraska, T.; Kleinschmidt, B.; Weinand, J.; Pude, R. Cascading Use of Miscanthus as Growing Substrate in Soilless Cultivation of Vegetables (Tomatoes, Cucumbers) and Subsequent Direct Combustion. Sci. Hortic. 2018, 235, 205-213. [CrossRef]

57. FAO. Good Agricultural Practices for Greenhouse Vegetable Crops: Principles for Mediterranean Climate Areas; FAO Plant Production and Protection Paper; Food and Agricultural Organization of the United Nations (FAO): Rome, Italy, 2013; ISBN 978-92-5-107650-7.

58. Barrett, G.E.; Alexander, P.D.; Robinson, J.S.; Bragg, N.C. Achieving Environmentally Sustainable Growing Media for Soilless Plant Cultivation Systems-A Review. Sci. Hortic. 2016, 212, 220-234. [CrossRef] 